\title{
URBAN SHRINKAGE AND REGENERATION OF AN OLD INDUSTRIAL CITY: THE CASE OF WAŁBRZYCH IN POLAND
}

\author{
EMILIA JAROSZEWSKA ๑ \\ Institute of Socio-Economic Geography and Spatial Management, Adam Mickiewicz University in Poznań, \\ Poland
}

Manuscript received: February 25, 2019

Revised version: April 16, 2019

JAROSZEWSKa E., 2019. Urban shrinkage and regeneration of an old industrial city: The case of Wałbrzych in Poland. Quaestiones Geographicae 38(2), Bogucki Wydawnictwo Naukowe, Poznań, pp. 75-90. 1 table, 7 figs.

ABSTRACT: The industry which was a driving force of the economy and contributed to the population growth in many cities for decades became later the source of their problems. The crisis of the activity of old industrial cities creating the economic base (especially of the traditional industry), provoked by the deindustrialisation process and in post-socialist countries additionally by the "shock" of the economic transformation, caused long-lasting and unfavourable changes in many areas. It resulted in the present process of shrinkage of old industrial cities in demographic, economic, social aspects as well as spatial ones (Bontje 2004; Oswalt 2005; Turok, Mykhnenko 2007; Pallagst et al. 2009; Cunningham-Sabot et al. 2010; Bontje, Musterd 2012; Hospers 2012, 2014; Haase et al. 2013; Pallagst et al. 2014; Stryjakiewicz 2014; Runge et al. 2018). This process can take a different course in different socio-economic patterns depending on the geographical situation and the time of observation. However, it leads to unfavourable results in each place, first of all to a decrease in the number of inhabitants. The aim of the article is twofold: (1) the identification and analysis of the process of urban shrinkage of Wałbrzych city as well as (2) the examination of different regeneration strategies adopted to mitigate negative effects of urban shrinkage. It is particularly important to understand this process and results of the adopted strategies especially in the context of the future development of this city which according to demographic forecasts will be shrinking in the long run.

KEY WORDS: urban shrinkage, old industrial city, regeneration strategies, Wałbrzych, Poland

Emilia Jaroszewska, Institute of Socio-Economic Geography and Spatial Management, Adam Mickiewicz University, Poznań, ul. B. Krygowskiego 10,61-680 Poznań, Poland; e-mail:emiliagp@amu.edu.pl

\section{Introduction}

The building of the post-industrial economy turned out to be particularly difficult and costly for a great number of cities where a considerable industrial potential was concentrated dominated by traditional industrial branches. The transition from the Ford to the Post-Ford model production (i.e. from the massive production to its flexible organisation) (Stryjakiewicz 1999; Domański 2000; Power, Plöger, Winkler 2010) resulted in the collapse of the economic base of many of them. This, in turn, brought about a series of negative after-effects leading to the crisis of cities observed since the 1970s (e.g. Beauregard 2003; Pacione 2005; Kuciński 2008; Knox, Pinch 2010; Majer 2014). It caused long-term and unfavourable changes in numerous old industrial cities affecting economic, social and material spheres. Consequently, the population started to decrease and the phenomenon intensified after some time, leading to the process of shrinkage in the long run 
(Reckien, Martinez-Fernandez 2011; Zborowski et al. 2012; Haase et al. 2013; Pallagst et al. 2014; Stryjakiewicz et al. 2014; Runge et al. 2015).

Contrary to western countries, the problems of cities of East-Central Europe, including Poland, occurred with the radical political and economic transformation at the beginning of the 1990s. In the period of socialism (1945-1989), these cities - in contrast to Western Europe - developed in different conditions (Parysek 2005; Węcławowicz 2007, 2013). I. Sagan emphasises (2000: 85) that "what was characteristic of socialist urbanisation was that it took place in industrialising societies deprived of private production means, those being the state's monopoly, and having centrally planned economic systems". Hence, new determinants of development, which appeared at the beginning of the 1990s with a radical political and economic change, contributed to the new division of cities into "winners" and "losers" of the post-socialist transformation (Parysek, Wdowicka 2002). While the beginning of the 1990s opened the opportunities for the dynamic development and growth of the first group, for the second group it created the conditions for the development of the urban shrinkage process. This resulted from direct outcomes of the system transformation causing the fall of industrial plants, and as a consequence an economic crisis of an entire city, and is related to a direct activity of an atypical mechanism that consists in the combination of negative effects of the system transformation with the interaction of the world processes, such as: deindustrialisation, globalisation and Europeanisation, or changes in demographic and social behaviour. The specifics of the shrinkage of post-socialist cities manifest itself also in the pace of this process (which is much faster in comparison to western cities) and the time it started. While many western cities began to shrink in the 1960s and 1970s, the post-socialist cities of East-Central Europe went through this process much later, at the end of the 20th century.

A rapid acceleration in the shrinkage of cities in Poland and other countries in East-Central Europe is related to the results of the second demographic transition (Lesthaeghe, van de Kaa 1986, after Kurkiewicz 2010: 50) that took place faster than in western countries. This process involves a unidirectional change in many types of demographic behaviour concerning marriage and replacement rates (Okólski 2005). Its effects include a change in lifestyle, the appearance of a new model of the family and household, an advancing ageing of society and a decline in birth rates which turned out to be one of the largest problems. According to J. Caldwell and T. Schindlmayr (2003), the reduction in the number of births resulted from uncertainty and a general lack of safety stemming from high unemployment and the fact that employment was not guaranteed. Hence, a decrease in the birth rate meant a "rational adjustment" of societies to the new post-socialist reality.

The combination of demographic changes and such factors as deindustrialisation, globalisation and the system transformation brought old industrial cities to an exceptional and difficult development path which results in the declining population and what follows, a decrease in their political and economic importance as well as a fall in the hierarchy of settlement units. In many of them, drastic changes caused by the 'shock therapy' in the economy contributed also to the 'shocking shrinkage of cities'.

In Poland, this process can best be exemplified by the city of Wałbrzych. This choice is justified by several reasons. Wałbrzych is an old industrial city with one of the highest population losses among cities with more than 100,000 inhabitants, and with severe socio-economic problems after the collapse of mining in the '90s. Moreover, several regeneration strategies are being implemented here (including such forms as, e.g. special economic zones (SEZ) and urban revitalisation projects). The population analysis of the shrinkage of Wałbrzych covers the period of almost 70 years. Such a long period allows following the development path of this city since the end of World War II, i.e. from the moment of its inclusion in the Polish border to the present-days.

\section{The context of urban shrinkage and regeneration}

Urban shrinkage has no single explanatory theory. The multi-aspect nature of this process makes it necessary to resort to many theoretical conceptions in order to get an insight into its mechanisms, pattern and effects (Stryjakiewicz et al. 2014). Also the term of shrinking city, 
despite the fact that it has been established in the literature, has not been clearly defined. This is confirmed by the variety of definitions related to this issue and different approaches to their operationalisation (e.g. Haase et al. 2014; Stryjakiewicz et al. 2014; Kantor-Pietraga et al. 2014; Bernt 2015; Stryjakiewicz, Jaroszewska 2016; Haase et al. 2017).

So far, diverse aspects of the urban shrinkage have been investigated, e.g. the identification of the reasons for the population decline, the description of development trajectory or analysis of planning solutions to mitigate its negative effects. However, there was no comprehensive approach to understand the shrinkage of cities. This gap was recently filled by A. Haase and others (2014), who developed a heuristic model of urban shrinkage, irrespective of its national or local specificity (Fig. 1). As it is emphasised by the authors of the model, it combines the three most important aspects: the causes, effects, and reaction to the changes taking place. It also indicates the relationships between them. However, its universality causes other important aspects related to its duration (long- or short-term shrinkage) and pace (rapid, gradual shrinkage) to be unspecified. The spatial dimension of the process of shrinkage is also an important issue, i.e. whether it concerns only the city within its borders, concentrates only in its selected areas or affects also suburban areas. Kantor-Pietraga et al. (2014) distinguished two dimensions of urban shrinkage, i.e. the 'real' shrinkage when the population decline concerns a city and its surroundings, and 'apparent' when the shrinkage of a city is the result of the suburbanisation process.

The criteria regarding the time, size of the population decline and the selection of other features (indicators) characterising the process of shrinkage are also unclear. This is due to the fact that urban shrinkage occurs at a different time, in different local systems with a different specificity of the current development. Hence, the development of a detailed definition including all aspects and at the same time referring to every shrinking city in the world is a particularly difficult challenge. According to the definition adopted in the CIRES project formulated by the Shrinking Cities International Research Network (SCIRN), "A shrinking city is a densely populated urban area that has on the one hand faced a population loss in large parts of it (for at least 5 years, more than $0.15 \%$ annually), and is on the other hand undergoing economic transformation with some symptoms of a structural crisis". This is the definition that will be used henceforth in this article.

Although the above definition emphasises the main cause of urban shrinkage which is the population decline, it should be noticed that the process of shrinkage should always be considered in

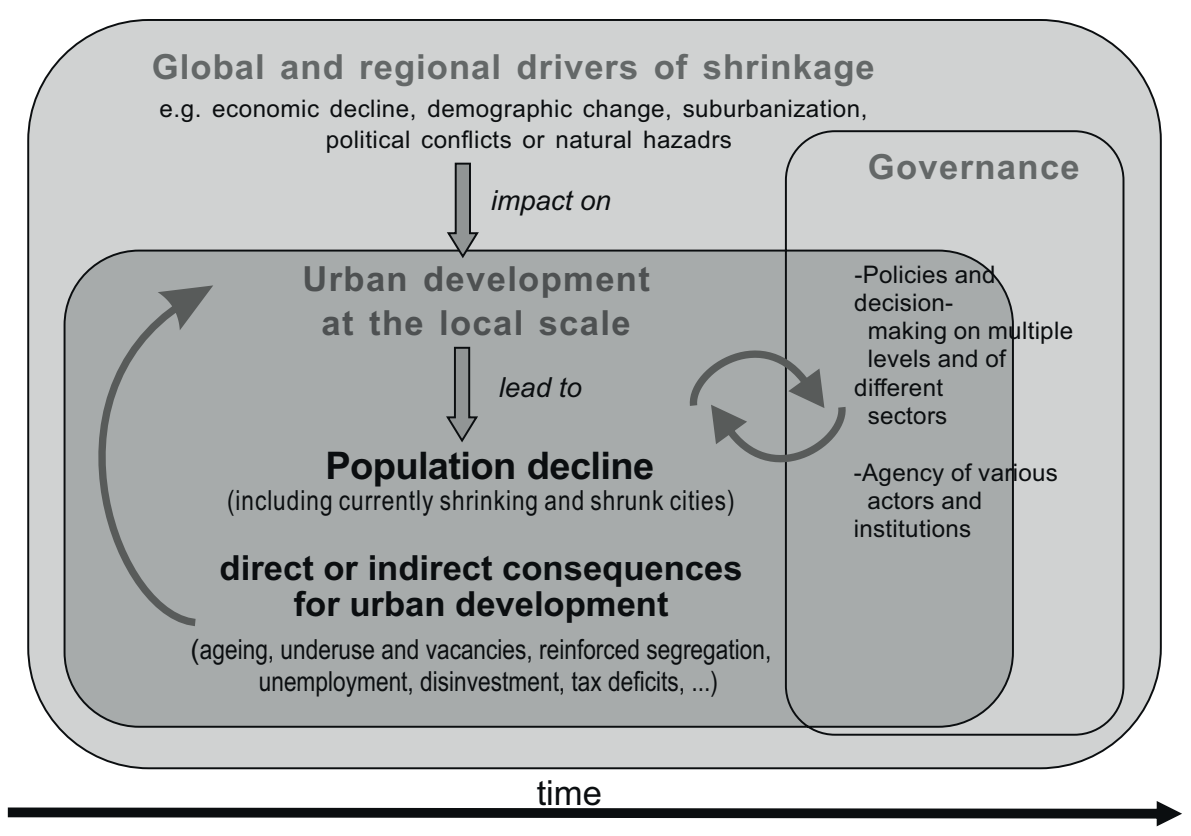

Fig. 1. Heuristic model of urban shrinkage. Source: Haase et al. (2014: 1525). 
many aspects, as a result of many other processes occurring simultaneously, which is at the same time the reason for subsequent changes in the highly complex system of the city. In this manner it will be treated herein. Limiting the explanation of this process only to the demographic aspect without analysing the impact of socio-economic determinants and factors - seems to be insufficient, although the decline in the population is undoubtedly its main cause and effect.

The answer to the question why cities are shrinking and what are the reasons (factors and conditions) behind it is not definite. Although the common occurrence of the process of urban shrinkage can be discussed, each case has different origins. In a complicated reality the cities operate, a set of causes can be found (e.g. Oswalt, Rieniets 2006; Riecken, Martinez-Fernandez 2011; Haase et al. 2014; Hospers 2012, 2014ab; Richardson, Nam 2014; Stryjakiewicz et al. 2014; Wiechmann, Bontje 2015), both external and internal in character, related, e.g. to the specifics of each city, its history as well as its political and socio-economic situation. Some of them, e.g. the deindustrialisation crisis and negative demographic changes, can play a pivotal role and affect the appearance of others, which is presented in this work on the example of Wałbrzych city.

The answer to the question about the proper regeneration strategies for shrinking city is also open. The experience of cities affected by shrinkage shows that there is no simple method of counteracting negative consequences of this process. The strategies adopted often depend on how local authorities perceive urban shrinkage and whether they are resigned to the fact that the number of inhabitants will keep declining. The strategies can seek adaptation to the conditions of shrinkage and planning for shrinkage (Hollander et al. 2009), as in the cities of East Germany (e.g. Wiechmann, Volkmann 2012); they can also be oriented towards regrowth and treat shrinkage as a transitional stage; or there can be no measures undertaken at all - the process is ignored (Danielzyk et al. 2002). Generally, the main objective of the strategies undertaken in shrinking cities is their regeneration. In the scientific literature one can find the interchangeable use of terms 'regeneration', revitalisation', or 'urban renewal'. Without entering into a broader discussion on the evolution and differences between the mentioned expressions described in the literature by, e.g. T. Kaczmarek (2001, p. 106), P. Roberts (2008, p. 14), W. Jarczewski (2009, p. 9), S. Kabisch, I. Sagan (2011, p. 91), A. Majer (2014, pp. 54-62), the present author proposes the term regeneration based on the definition offered by P. Roberts (2008, p. 17), according to which this is a "comprehensive and integrated vision and action which leads to the resolution of urban problems and which seeks to bring about a lasting improvement in the economic, physical, social and environmental condition of an area that has been subject to change". In this approach, the regeneration process of a shrinking city relates to the broader aspect of its transformation which embraces the whole change involving the integration of measures within its socio-demographic and economic structure, housing, technical and land-use infrastructure, social infrastructure, and also activities improving its perception both outside and in the eyes of the inhabitants. In other words, these strategies should allow for complex actions related to three spheres: 'hard', 'soft' and 'image-related' (Hospers 2012, 2014ab).

\section{Causes and effects of the shrinkage of Wałbrzych}

Wałbrzych is situated in south-western Poland in Dolnośląskie (Lower Silesia) Voivodeship, close to the borders with the Czech Republic and Germany (Fig. 2). After Wrocław - the voivodeship's capital - it ranks as the region's second centre with 113,621 residents (as at 31 December 2017).

By the mid-19th century, Wałbrzych had grown into an important industrial centre. The chief industries of the city and the entire region were mining for hard coal and coke-making. Right after World War II, it was the biggest industrial centre in the region. Apart from mining, there were also other industrial establishments, mostly coking plants, clothing and textile plants, as well as glass and ceramics works. The period of transformation of the Polish economy initiated in 1990 has been the time of very deep changes in the economic structure of the city and the entire region. Although the situation in the city has improved in many aspects in recent years 


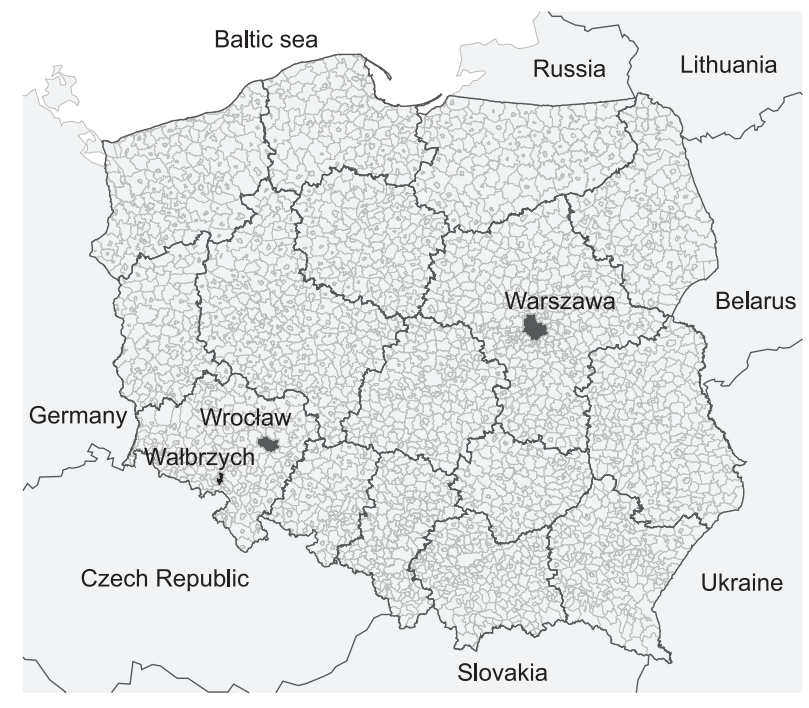

Fig. 2. Location of Wałbrzych in Poland. Source: own compilation.

(creation of new jobs, decline in unemployment, revitalisation of run-down areas, housing investments), the population loss has been continuing since the 1990s (Fig. 3). In the years 1990-2015, the population decreased by $18.12 \%$, which made Wałbrzych one of the most shrinking cities in the country (Jaroszewska, Stryjakiewicz 2014). According to the demographic forecast of the Central Statistical Office (Statistics Poland), the city will have less than 100,000 inhabitants $(99,187)$ in 2030 , thus achieving the population number from 1950/51. In turn, in 2050, the predicted population will be only 74,463 , which means that - if the forecasts prove successful - Wałbrzych will shrink by almost half $(-47 \%)$ compared to the population peak year 1989 when it had 141,504 inhabitants.

\section{Causes of the shrinkage of Wałbrzych}

In the case of this city, several reasons for the shrinkage can be distinguished. The first one historical reason - is related to the formation of an industrial function of the city, and then to the breach of the evolutionary development path as a result of the changes in the national borders after World War II, which in practice meant the entire population replacement and the imposition of the socialist development path. As a result, the functioning of the city was dependent on the one industrial branch. Another reason - demographic - concerns both the endogenous development of the city's population and also the influence of more general demographic processes related to the after-effects of the so-called second demographic transition, including the aging process. The next cause - changes in the economic base and problems of the local labour market - due to a citygenic role of the industry and due to the consequences of its liquidation is treated as a major reason for the shrinkage of this city. The following two causes, although not directly responsible for the shrinkage, yet were able to - in the author's opinions - reinforce the influence of

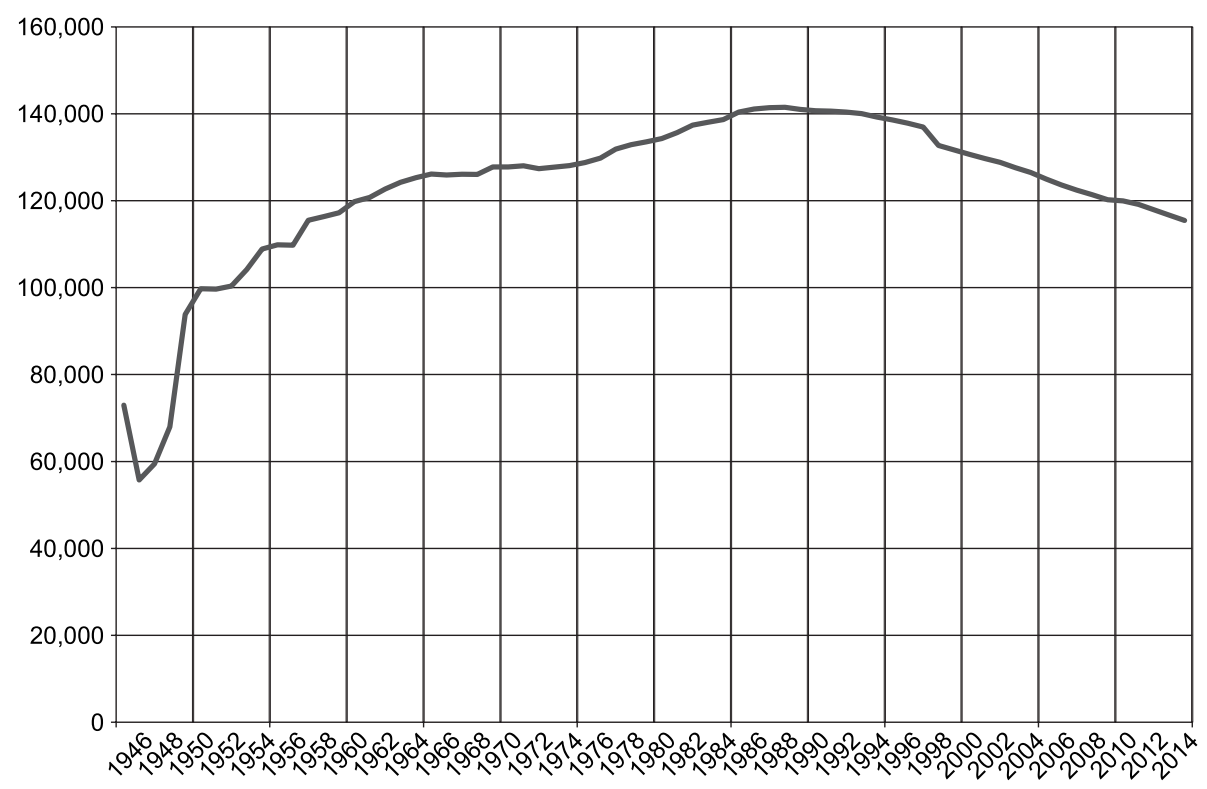

Fig. 3. Population of Wałbrzych in the years 1945-2015. Source: own compilation based on Central Statistical Office (GUS) data. 
dominating reasons. Specific socio-cultural features of the residents of Wałbrzych, resulting on the one hand from the structure of people who settled there after the war and, on the other, from the material and non-material influence of mining and the lack of this influence (after the liquidation of mines) on the life of the local community later, were important for the decision about migration and provided the grounds for the series of psychosocial problems. The process of urban shrinkage was also affected by spatial, infrastructural and environmental reasons. Bad housing conditions, a polluted environment and mining damages were one of the causes of the intensification of problems in given parts of the city, contributed to a decrease in the population number and the presence of uninhabited flats. The process of urban shrinkage was also affected by political decisions made both at the local and central levels, the consequences of which were of crucial importance for this city. As was mentioned above, two of the reasons: demographic and economic can be recognised as dominating and therefore they will be presented in more detail below.

\section{Demographic causes}

The population of Wałbrzych, in the first years after the war was subject to considerable fluctuations connected to the inflow of the Polish population and the displacement of the Germans. However, as early as in 1947 and then throughout the entire socialist period, an increase in the number of inhabitants was recorded, while at the same time it has to be acknowledged that the growth rate was significantly lower than in cities and in the country in general (Fig. 4). This was caused by a massive migration of people resulting, e.g. from the weak attachment of the people who settled there to the city and its high pollution related to mining. Migration was also caused by deteriorating housing conditions stemming from the lack of housing investment. In terms of the unfavourable, negative balance of migration, Wałbrzych was different from other cities in the country where the migration movement contributed to a steady increase in the population number.

The migration loss in Wałbrzych was compensated by a high birth rate throughout the entire socialist period. The turning point came in 1990.
Since then the number of inhabitants has been regularly falling down. In the years 1990-2015, the population number decreased by 25,500 people $(-18.1 \%)$; the highest loss $(-3 \%)$ was recorded in 1999 as compared to the previous year. It was the time of the accumulation of social problems related to the liquidation of mines.

Since the beginning of the 1990s economic migrations both inside the country and abroad ${ }^{1}$ have been among the reasons for a decrease in the population. In the years 2001-2015, among the 14,700 people who decided to emigrate from Wałbrzych to other Polish cities, as many as 37.4\% were persons aged $20-34$, with $49.2 \%$ in 2009 . In turn, $69.5 \%$ of all migrants in 2002-2015 were moving to other cities in Poland, which means that the outflow was not related to the suburbanisation process, i.e. migration to the suburbs. Moreover, $48.5 \%$ migrants chose cities situated in Dolnośląskie Voivodeship for a new place to live. Undoubtedly, the rapidly developing metropolitan area of Wrocław is a magnet attracting the residents of Wałbrzych. Among the migrants moving abroad, the majority went to Western Europe, especially to Germany and Great Britain (37\% and $24 \%$ respectively). Apart from migration, a negative birth rate maintaining for years

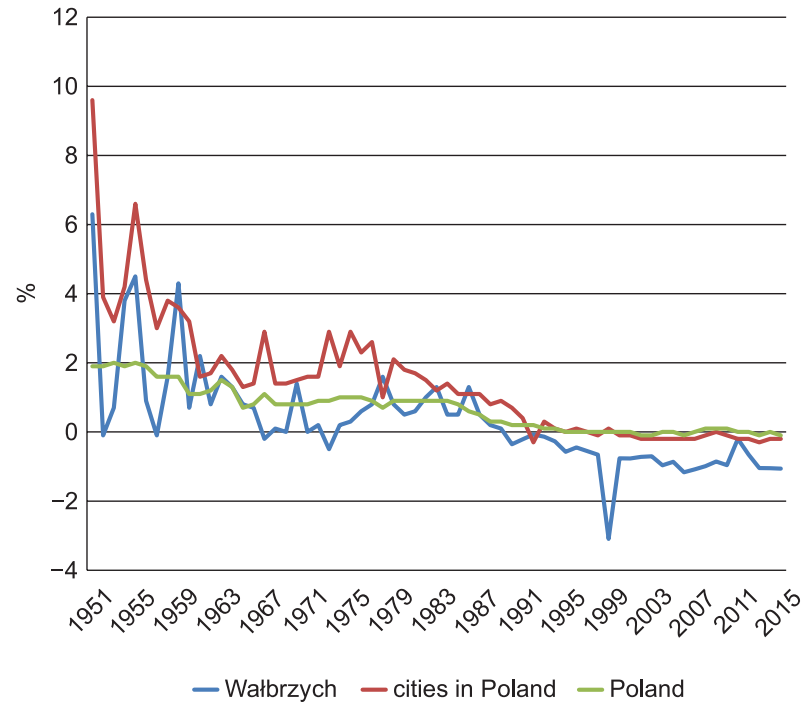

Fig. 4. Annual population growth/decline in Wałbrzych as compared with the country in 19452015.

Source: own compilation based on Central Statistical Office (GUS) data.

It should be remembered that not all migrations are registered, in reality they can be $20-30 \%$ greater. 


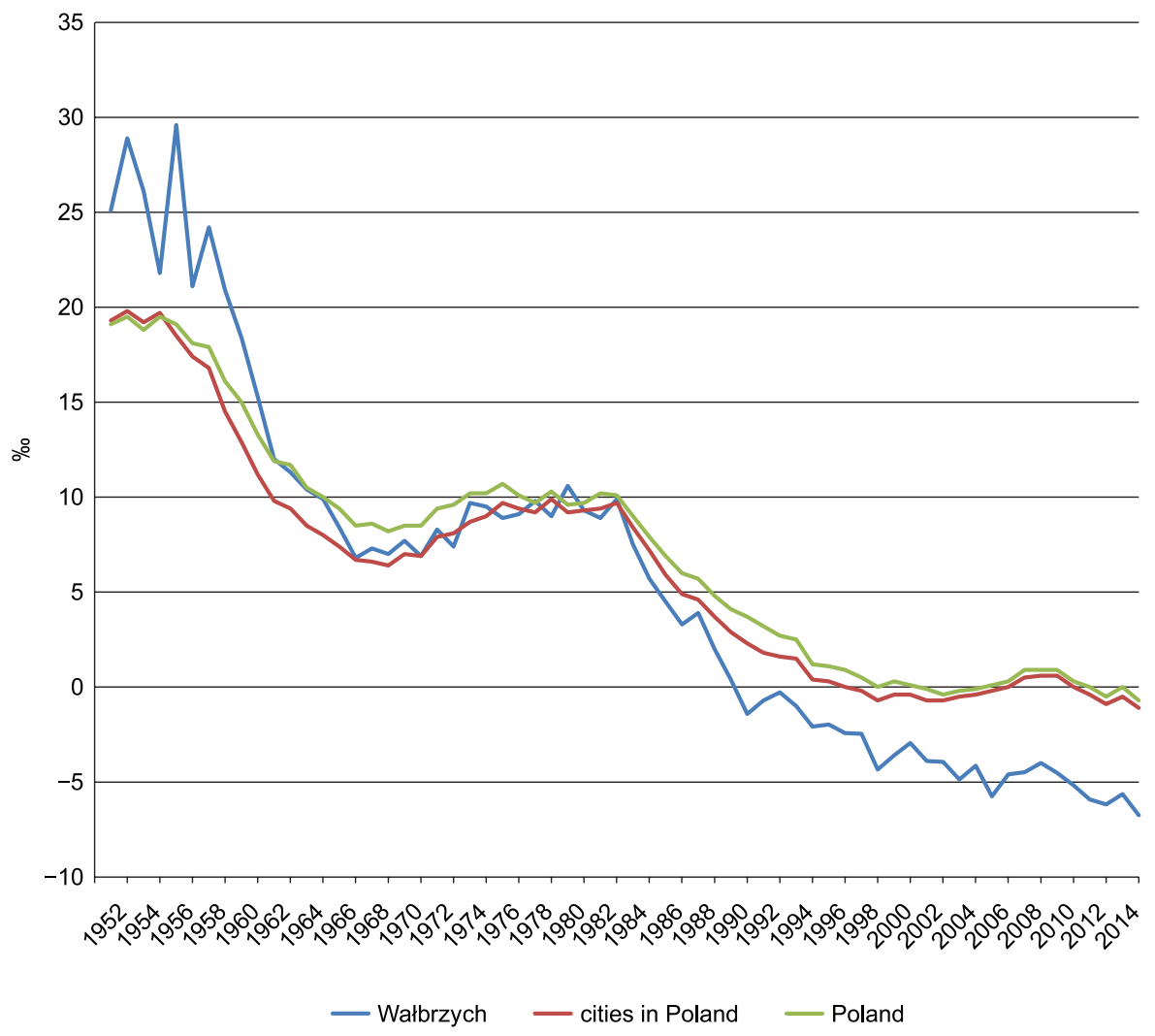

Fig. 5. Natural increase/decrease in Wałbrzych, cities in Poland and Poland in 1952-2015. Source: own compilation based on Central Statistical Office (GUS) data.

intensifies the unfavourable demographic situation. In the first years after the war, the record number of children was born which was related to the young age of newcomers (Fig. 5). However, it decreased over the next years as a smaller number of people born during the war reached birth age and young residents left the city. A natural birth rate increased again at the turn of the 1970s and 1980s because the baby boom generation entered reproductive age, and then since 1984 it has been declining. Since 1991 the birth rate has been negative with the lowest coefficient of $-6.7 \%$ o (in 2015) in the city's history. Moreover, as can be noticed in Fig. 5, as early as in the mid-1980s, Wałbrzych negatively stands out against other cities and the country.

Based on the natural growth/loss coefficient and a net balance of migration, the trend in the changes of the population development in Wałbrzych in 1975-2015 was determined using the typology of demographic development by J.W. Webb (Kosiński 1967) (Fig. 6). It can be noticed that in 1975-1991 (except for 1990) Wałbrzych was characterised by the development type of the population number resulting mainly from a positive natural growth which except for the years 1981, 1982, 1986, 1987, 1988 - compensated for a negative migration balance (type A). In the entire period analysed, only in 1986 the growth of the population in Wałbrzych stemmed rather from a positive migration balance than a positive natural growth (type C).

Starting from the 1990s (except for 1991) the city has a regressive type of the population development. While at the beginning of the socio-economic transformation, the migration loss affected the demographic growth, in the last years a new path of the city's demographic shrinkage emerged characterised by the domination of the natural loss over the migration loss (type F), which would increasingly influence the city's shrinkage in the long run.

\section{Economic causes}

Dominated by the industrial monoculture, Wałbrzych was in a difficult, even - as some authors indicate - tragic situation at the beginning of the 1990s (Skiba 1997; Gajda 2010; Rakowski 2009). As early as in 1990, the problems of so far 


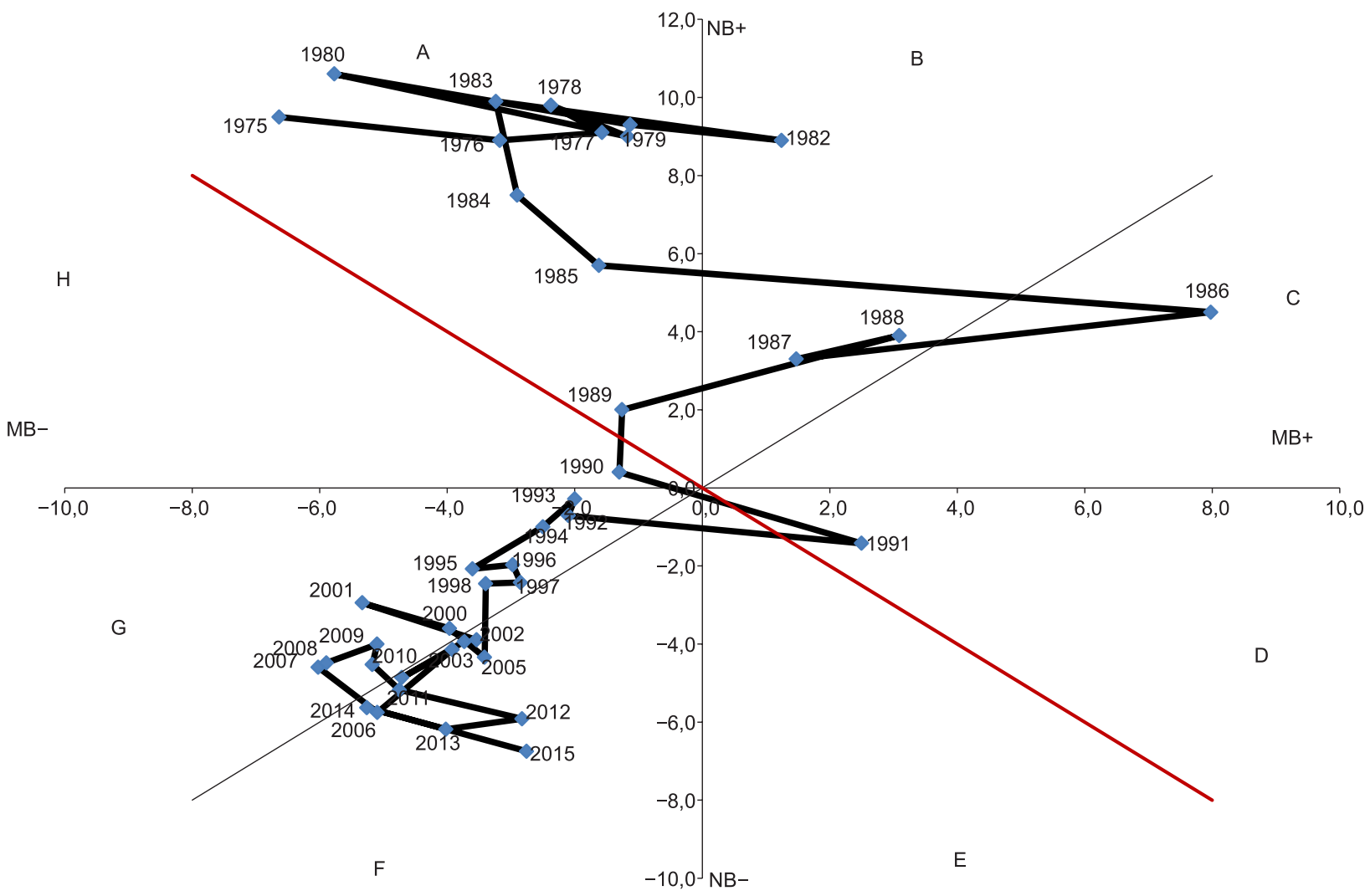

\begin{tabular}{|l|l|l|l|}
\hline \multicolumn{2}{|c|}{ Positive types (population growth) } & \multicolumn{2}{c|}{ Negative types (population decrease) } \\
\hline $\begin{array}{l}\text { Type A } \\
\text { NG+ }>|\mathrm{MB}-|\end{array}$ & $\begin{array}{l}\text { positive natural growth compen- } \\
\text { sates for negative migration balance }\end{array}$ & $\begin{array}{l}\text { Type } \mathrm{E} \\
|\mathrm{NG}-|>\mathrm{MB}+\end{array}$ & $\begin{array}{l}\text { negative natural growth is not } \\
\text { compensated by positive migration } \\
\text { balance }\end{array}$ \\
\hline $\begin{array}{l}\text { Type B } \\
\text { NG+ }>\mathrm{MB}+\end{array}$ & $\begin{array}{l}\text { population growth stems more from } \\
\text { positive natural growth than posi- } \\
\text { tive migration balance }\end{array}$ & $\begin{array}{l}\text { Type } \mathrm{F} \\
|\mathrm{NG}-|>|\mathrm{MB}-|\end{array}$ & $\begin{array}{l}\text { loss in population number results } \\
\text { more from negative natural growth } \\
\text { than negative migration balance }\end{array}$ \\
\hline $\begin{array}{l}\text { Type C } \\
\text { NG+ }<\mathrm{MB}+\end{array}$ & $\begin{array}{l}\text { population growth stems more from } \\
\text { positive migration balance than } \\
\text { positive natural growth }\end{array}$ & $\begin{array}{l}\text { Type } \mathrm{G} \\
|\mathrm{NG}-|<|\mathrm{MB}-|\end{array}$ & $\begin{array}{l}\text { loss in population number results } \\
\text { more from negative migration bal- } \\
\text { ance than negative natural growth }\end{array}$ \\
\hline $\begin{array}{l}\text { Type } \mathrm{D} \\
|\mathrm{NG}-|<\mathrm{MB}+\end{array}$ & $\begin{array}{l}\text { negative natural growth is compen- } \\
\text { sated by positive migration balance }\end{array}$ & $\begin{array}{l}\text { Type } \mathrm{H} \\
\mathrm{NG}+<|\mathrm{MB}-|\end{array}$ & $\begin{array}{l}\text { positive natural growth does not } \\
\text { compensate for negative migration } \\
\text { balance }\end{array}$ \\
\hline
\end{tabular}

Fig. 6. Direction of changes in the demographic development of Wałbrzych in the years 1975-2015 based on the Webb typology.

Source: own compilation based on Central Statistical Office (GUS) data.

hidden unemployment arose. According to the District Labour Office in Wałbrzych (1990), there were 9,320 people registered at the time and only 39 jobs offered (Table 1). The heaviest blow for the local economy, however, was the decision of November 29, 1990 putting three mines in Wałbrzych ("Victoria”, "Wałbrzych", "Thorez") into liquidation. The decision resulted from mine unprofitability related to the high costs of the excavation of hard to reach coal deposits and the underinvestment mentioned earlier, technological backwardness, the global decline in demand for coal and external competitiveness. According to the sources available ${ }^{2}$, as late as in 1993, there were 7,251 miners employed in mines, whereas about 20,000 people in total worked in mines and plants linked to them (about $50 \%$ of all people working in the city). A difficult situation

2 The program of liquidation and restructuring of employment in the mine "Julia" for 1993-1995. Wałbrzych 1993 (after Urbański 2004). 
Table 1. Number of the unemployed and job offers in the Labour Office in the years 1990-2015 (data as at the end of December).

\begin{tabular}{|l|c|c|c|c|c|c|c|}
\hline & $1990^{*}$ & $1992^{*}$ & $1997^{*}$ & 2002 & 2005 & 2010 & 2015 \\
\hline Unemployed registered & 9,320 & 21,070 & 10,432 & 15,518 & 12,717 & 7,079 & 4,088 \\
\hline With right to unemployment benefit & - & - & 3,490 & 3,024 & 2,056 & 1,658 & 601 \\
\hline Number of job offers & 39 & 70 & 28 & 0 & 0 & 44 & 1,242 \\
\hline
\end{tabular}

*data refer to the Wałbrzych region.

Source: own study based on the reports of the District Labor Office in Wałbrzych (1990/97) and the Poviat Labor Office in Wałbrzych.

was additionally aggravated by generally a bad economic condition of all industrial plants located in the city. Initial plans to hire miners in other branches turned out impossible to implement. Many other industrial plants did not survive the transformation, including the porcelain factory "Książ", built in the 1980s, which failed in 2004. Another porcelain factory "Wałbrzych" was eventually shut down in 2012.

The liquidation of mines caused a rapid increase in unemployment, bigger than the country's average. As Skiba wrote (1997: 21): "the problem of fired miners cannot be described with the most accurate indices". The same author notices that these indices did not consider, e.g. persons on temporary mine leave and included in a periodic social protection. Moreover, many unemployed were not registered in the Labour Office. A dramatic situation was also reflected by no entitlement to benefits of a great majority of the registered unemployed and a lack of job offers (Table 1). It should be kept in mind that in those years a migration balance remained negative which influenced the lowered unemployment statistics.

According to the official statistics, the record year in which the highest proportion of the unemployed was noted in Wałbrzych was 2002 with the unemployment rate of $28.1 \%$. It was one of the highest indices in the country (Fig. 7). However, according to Rakowski (2009: 383), a real unemployment could have reached even $50 \%$ in 2002-2006. The situation was additionally aggravated by the fact that the city was inhabited by low-skilled people who had either elementary education or finished vocational mining schools. Finding a different job became a significant problem. What is more, among the unemployed in 2002 (i.e. in the year with the highest unemployment in the city) $74 \%$ were young people at the age of 18-34. No prospect of finding a job was the main reason why young people left the city.
The data on the number of employed prove the depression of the labour market. While in 1989, just before the transition from the centrally planned economy to a free market economy, there were 58,196 of the employed (in 1977 it was $59,947)$, in 2000, i.e. after the liquidation of mines, the number of working people, according to the official data, dropped by $48.7 \%$ ( 28,344 persons). In the same period, the number of persons working dropped by $65.4 \%(18,202$ persons) in the industry (WUS, GUS).

Despite a gradual improvement in the labour market in Wałbrzych, e.g. thanks to the investment in WSEZ (Wałbrzych Special Economic Zone), the unemployment rate in the city remains at the higher level than in the country or voivodeship. One should bear in mind that not all the unemployed registered at the beginning of the 2000s found jobs. Some of them reached the retirement age, stopped looking for a job or left

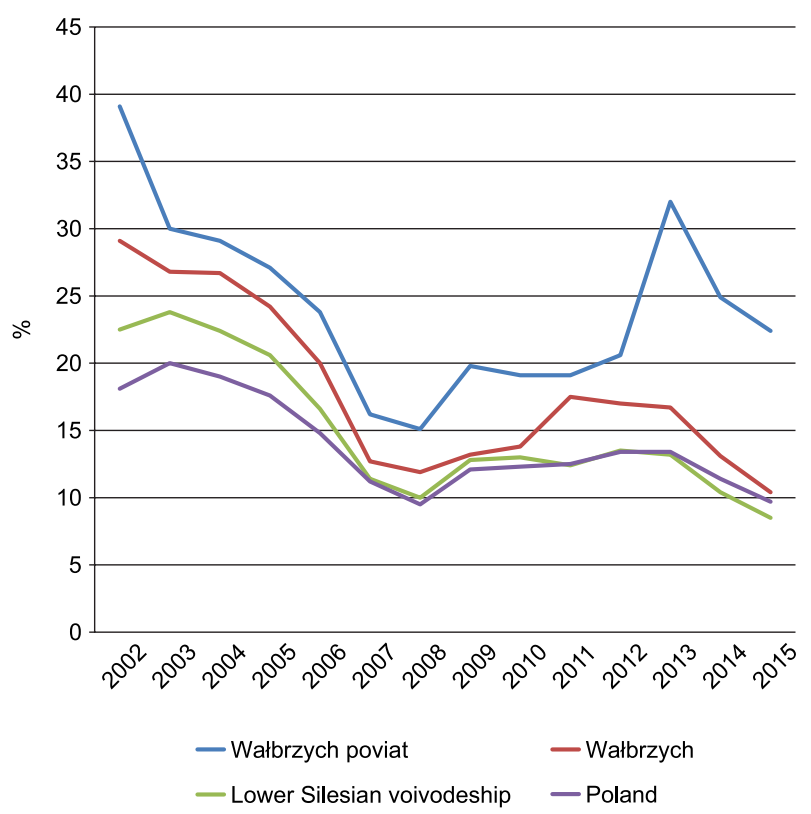

Fig. 7. Unemployment rate 2002-2015 (\%) (end-of-theyear figures).

Source: own compilation based on Central Statistical Office (GUS) data. 
the city. According to the Poviat Labour Office in Wałbrzych, at the end of December 2015, the unemployment in the city and the poviat was respectively $10.5 \%$ and $22.5 \%$.

\section{Effects of the shrinkage of Wałbrzych}

The first type of effects that after G.J. Hospers $(2012,2014)$ can be called hardware, is related to the influence of the urban shrinkage on the city's physical fabric. It is manifested in numerous uninhabited flats, public post-industrial buildings and in the deteriorating quality of the public space as well as an ineffective use of technical infrastructure. The loss of inhabitants results in an unfavourable economic situation of the city, related to low budget revenues and a growing city debt.

Undoubtedly, a visible manifestation of the process of urban shrinkage is the physical and aesthetic degradation of housing substance which concerns particularly old industrial districts of the city. The buildings, almost undamaged during World War II, throughout the entire socialist period up to this day have not been renovated (except for sporadic, minor repairs), or even restored. This negligence stemmed from the fact, among other things, that old buildings (constructed in capitalism) were devalued by a socialist country and the construction of large blocks of flats made from large plates was preferred. According to the data from the Municipal Office in Wałbrzych (Urzą Miejski w Wałbrzychu, 2013), 97\% of residential buildings owned by the commune were constructed before 1945, the technical condition of $42 \%$ of municipal buildings is poor and $17.29 \%$ (121 buildings) are due for demolition. In Wałbrzych, in contrast to German cities, residential blocks of flats built during the communist period are not demolished. Large-panel housing estates which have better technical conditions than older tenements and better access to services (e.g. proximity of shopping centres) are still attractive to live and spend free time.

Except for uninhabited houses and degraded buildings, there is also a problem of free commercial premises. The city is full of empty window displays and service premises. This issue also concerns a well-maintained city centre and the market which, despite considerable aesthetic improvements, are not perceived as attractive for spending free time. In local media this important part of the city is called "the centre of boredom" (Panorama Wałbrzyska 2014).

The industrial function of the city also caused the problem with the development of large post-industrial areas connected primarily with coal mining that appeared after the liquidation of mines. Mining yards were subject to technical and biological recultivation and some were designated for recreational purposes (walking and cycle paths, race tracks for off-road cars). Unfortunately, at the beginning of the restructuring period and liquidation of mines, precious historical industrial buildings were demolished (Kosmaty 2011).

As a consequence of a decline in the population, the schools are shut down. In 2015, 8,900 pupils attended elementary and middle schools. In comparison to 1989 , when 18,000 pupils were educated in elementary schools, it is a dramatic drop which triggered the liquidation of schools causing additional social tensions. In 2013 only, the city authorities closed 6 schools, and in 2015 another two ones. Inhabitants and teachers often opposed the liquidation of schools which led to numerous protests. An additional problem was the development of abandoned buildings. One of the positive solutions was the adaptation of some to municipal and social apartments.

A low potential of the city's income results also from the decreasing number of the population and the problems following liquidation of mining. In 2014, per capita income from PIT revenues accounted for 798.04 zlotys in Wałbrzych and was much below the average for other large Polish cities (1,278.46 zlotys) (Urząd Miejski w Wałbrzychu, 2016b). In 2015, Wałbrzych was also the most indebted city in Poland - the proportion of debts to income was $95.1 \%$. It was the most indebted city per inhabitant (4,565 zlotys) as well.

The process of urban shrinkage triggers some unfavourable results which, according to G.J. Hospers $(2012,2014 \mathrm{ab})$, can be included in the results of a software type. These are changes in the socio-demographic structure of a city related, e.g. to the loss of human capital such as the outflow of young and creative people and the ageing of the population.

The long-term loss of residents causes unfavourable consequences in the form of the disturbance of the age structure which at the persistent 
low birth rate is leading to further intensification of unfavourable demographic changes, especially the ageing process.

Considerable proportion of old people can be found in old industrial districts where housing conditions are often very bad (e.g. lack of central heating or bathroom in an apartment) which is particularly difficult for this group of residents. The challenge of particular importance is the ageing of lonely inhabitants whose children left homes, so-called 'empty nesters'. When children move far away, an additional problem of ensuring everyday care arises. The need for the elderly care and for social welfare homes or seniors' day centres increases. In 2015, the share of the elderly in the population of Wałbrzych was $23.6 \%(27,281$ persons) and was above average for cities in the country (21.3\%). At the same time there were two social welfare homes, including the one just built in 2014, with 97 places in total.

Negative social effects connected with poverty, the degradation of social status are also soft in character. As long as the economic base was grounded on coal mining, social differences were not so visible. It was not until after the transformation that many problems come up. They were related to the concentration of negative social phenomena in selected city areas and the creation of 'new' poverty enclaves (Rakowski 2009) especially in old polluted industrial districts where the lowest-paid miners lived.

A major sore point of the city which appeared after the liquidation of mines is illegal coal mining in so-called poor's shafts (Rakowski 2009; Gajda 2010; Krygowska 2016). Even 2,000 people were estimated to work there at the beginning of the first decade of the 21st century. This life-threatening way of mining, performed in poor conditions mainly by unemployed former miners, proved fatal for some of them. At the time it was a subject often discussed not only in local and national media but abroad as well. And although some years ago the city's authorities ensured that there were no more poor's shafts, this problem still exists. It is even more serious because the next generation is already working there, i.e. children of former miners (Dziennik Gazeta Prawna 2014). As has been reported by local media, as many as 200-300 people may earn this way.

The software type results were also manifested in Wałbrzych by the crisis of political elites, the culmination of which took place in 2010 when the self-government election had to be repeated due to the corruption related to winning electoral votes.

The problems connected with the liquidation of mining led to the consolidation of the stereotype of Wałbrzych as a city of the unemployed, poor's shafts, social pathologies and political corruption. This, in turn, was reflected in a negative image of the city, created not only by local or national media but also outside the country and which can be defined as the mindware result of the city's shrinkage (Hospers 2012, 2014ab). The image they create is of a fallen city with no future. Especially poor's shafts operating in the city attracted national as well as foreign media (Jaroszewska 2014). And although significantly fewer people work in poor's shafts than a decade ago, the city is still associated with them. This problem is emphasised in almost every publication on the city, even if it deals with completely different issues.

The unfavourable image of the city was also reinforced by the results of various rankings related to cities' attractiveness in which Wałbrzych ranked the worst. For instance, according to "Magnetism of Polish cities" (Young, Rubicam 2009), Wałbrzych was recognised as the most revolting place in Poland (next to Bytom and Ruda Śląska). In the ranking of 2014, carried out by the country's weekly Polityka which concerned the quality of urban life in the largest 66 cities in the country, Wałbrzych took the last position (Niezbednik... 2014); whereas in the ranking of the online news service Wirtualna Polska it achieved a status of the worst city to live in Poland in 2015. The criteria the mentioned rankings were based on could raise doubts; nevertheless their results reflect the preservation of the negative image of the city in society.

\section{Regeneration of Wałbrzych - a real chance or utopia?}

As can be found in the introduction to “Courage of Utopia" by G. Picht (1981), "to build the future is to know first of all what we want it to be like". Building the future of the shrinking city, such as Wałbrzych where the effects of mining liquidation are still noticeable and unfavourable 
demographic processes connected to a negative natural growth and to inhabitants' ageing exclude their quantitative regrowth seems to be an exceptional challenge. Leo H. Klaassen (1988: 269), on the other hand, remarks that the future becomes present in time and later it becomes the past. Therefore, the recognition and acceptance of the process of urban shrinkage and adaptation to reality is of key importance for the future of shrinking cities. Once this condition is fulfilled, its regeneration will not be a utopia understood (by the dictionary of the Polish language PWN) as "an intention impossible to materialise", but will become a real chance.

\section{Strategies mitigating negative effects of the shrinkage of Wałbrzych}

One of the most urgent strategies in the city after the liquidation of mining was the improvement to the local labour market. The actions to deal with the issue started the same year the last mine was shut down. The problems of the city needed support not only from the local authorities, but mainly from the government. A decided majority of assistance programmes addressed to Wałbrzych was intended to reduce unemployment by stimulating entrepreneurship (Urząd Miejski w Wałbrzychu, 2005).

The most important step taken was the creation of INVEST-PARK of the Wałbrzych Special Economic Zone (WSEZ) in 1997 (three years after the Polish parliament had passed the Special Economic Zones Act). The creation of zones, i.e. selected areas designated to run business activity on favourable terms (e.g. tax exemptions) aimed to reduce unemployment in areas especially affected by the "shock" of transformation. Unfortunately, the tragedy of the city was that an increase in new jobs in the Wałbrzych subzone occurred slowly in relation to the number of unemployed (Table 1).

Despite the high unemployment, WSEZ investors had many problems, especially in the initial period, with finding not only highly skilled workers (e.g. managers with technical education and managerial staff), but also those with lower qualifications. This was mostly due to the monofunctional character of the region, for years oriented towards mining. Also schools were geared to educating people working in this sector of the economy. When the situation on the labour market had changed, many retraining programmes were organised to prepare people for other occupations.

The largest group of investors in the zone are those from the automotive industry manufacturing car sub-assemblies, including Japan's Toyota. Unfortunately, the concentration of firms from a single industry poses a threat best illustrated by the latest world crisis when the first WSEZ investor - Takata Petri - decided in 2009 to liquidate its Wałbrzych plant and move production to a special zone in Romania, where the labour cost is lower.

After more than 20 years, there is no doubt that the inflow of investment to the Wałbrzych zone has substantially improved the situation on the local labour market. It tops various ranking lists as the best performing zone in the country. Today some 7,000 people work in its Wałbrzych city section, while many residents have also found jobs in local firms providing all kinds of services or subcontracted to the businesses located there (unfortunately, this indirect effect is hard to measure in figures).

New opportunities in the form of access to EU funds opened for Wałbrzych after Poland had joined the Community. So far, the city has absorbed means for the implementation of many projects, mainly infrastructural but also cultural, including joint transborder ones with the neighbouring towns in the Czech Republic. Thanks to support from the EU funds (Sectoral Operational Programme 2004-2006, Regional Operational Programme for the Voivodeship of Lower Silesia 2007-2013), the Wałbrzych authorities were able to proceed with most of the planned urban regeneration projects (which included revitalisation of the degraded areas). In 2004 the Local Programme for the Revitalisation of Wałbrzych City for the years 2004-2006 was passed, followed in 2008 by the next programme covering the years 2008-2015. It gives priority to the revitalisation of the downtown and postpones the reclamation of the former coal-mining areas to later years. The first projects involved the renovation of historic tenement houses and the modernisation of the public space.

A turning point in the construction of the city's future seems to be the decision to include Wałbrzych - next to Eódź and Bytom - in the pilot programme under the National Revitalisation 
Plan (NRP) which serves to develop a model solution for revitalisation. Thanks to this decision the city received special funds for revitalisation. In 2016, the new 2016-2025 Commune Revitalisation Programme (CRP) for Wałbrzych City was drawn up. This is the first urban document where the term "shrinking city" was used. It appears to be a very important step towards real measures considering challenges of the urban shrinkage which can be proved by the following record: "The decreasing population of Wałbrzych causes ever higher operation costs due to a low intensity of land-use and high expenditure on infrastructure. The revitalisation measures have to counteract the main problem which is the shrinkage of Wałbrzych." (Urząd Miejski w Wałbrzychu, 2016a: 17).

One of the most important revitalisation challenges turned out to be the mine Julia which is one of the largest complexes of former mine buildings in the city that fortunately survived. In 1999, after the decision on the liquidation of mines, the Industry and Technology Museum was created there because of the historical character of the place (Julia is the oldest and best preserved complex of historical industrial buildings of the end of the 19th and the beginning of the 20th century). Unfortunately, through the lack of means, almost no outlays were made on modernisation and protection of historical buildings. The museum operated for a decade in the buildings not changed after the liquidation and which deteriorated without proper conservation. They were also occasionally robbed.

In 2008, the Wałbrzych Commune received EU funds for the revitalisation of the building. The cost of the revitalisation was a total of 52.5 million zlotys, of which 35.7 million was funded by the EU. The first stage of revitalisation was completed in 2014, although initially it was planned in 2012. During the process, however, it turned out that projected amounts were quite insufficient. The project ended up over three times more costly, its estimated value until that moment was over 166 million zlotys. Such a significant increase in expenses results, e.g. from mistakes and the unreliable inventory of the area, the need for finding a new contractor and numerous corrections and project changes.

Despite many difficulties, Wałbrzych can be proud of the new complex called Former Mine
Science and Art Centre, the activity of which goes beyond that of a museum (next to historical buildings and exhibits, visitors can listen to the history and culture of mining told by guides who are former miners). The complex also includes the seat of the Wałbrzych Cultural Centre, Song and Dance Ensemble 'Wałbrzych', Unique Ceramics Centre and Temporary Exhibition Centre. In addition, there is a small hotel and office space for some non-government organisations. However, too extensive a change in the character of some buildings can cause certain dissatisfaction (especially to those who visited the place before revitalisation), e.g. the building of the old mine bathhouse of 1915 which, as part of the process, was transformed into a concert hall and lost its uniqueness.

Nevertheless, the Former Mine Science and Art Centre is - next to Książ Castle - the main tourist attraction of the city. Moreover, Former Mine, as the only such building in Lower Silesia, and one of the seven similar places in Poland is listed on the European Route of Industrial Heritage (ERIH). It is also the new - due to its function, and old at the same time - because of the mining past - symbol of Wałbrzych. The mine is an important meeting spot for creating and passing the identity and for preserving local cultural heritage related to the mining past of the city.

The regeneration process is also supported by numerous cultural projects, including joint transborder ones with the neighbouring centres in the Czech Republic. Moreover, there are many sports events in the city. Wałbrzych attempts to regain the leading position in the Sudety region as well. In 2012 the city authorities created the Wałbrzych agglomeration for the cooperation between neighbouring communes for mutual development and to maximise chances of receiving EU funds under Integrated Territorial Investments (so-called ITIs) in the EU 2014-2020 financial perspective. The positive changes observed in the last years make Wałbrzych be perceived as a city that "rises from its knees" (Gazeta Wyborcza 2013) or is even 'reborn' (Gazeta Wyborcza 2014). The search in 2015-2016 for the 'golden train'3,

\footnotetext{
The legendary German Nazi train was buried in an underground tunnel in Lower Silesia in January 1945 toward the end of World War II. A wealth of treasure and military secrets were supposed to be hidden inside its armoured carriers.
} 
which attracted also foreign media, contributed to a better image of the city. Although the train was not found, once an ugly and poor mining city, Wałbrzych suddenly became a city of secrets and treasures.

\section{Summing-up}

Looking at the urban shrinkage of an old industrial city such as Wałbrzych it can be stated that to understand its nature various internal and external drivers of local development need to be analysed. However as in this case, some of them such as the economic decline or negative demographic changes can play a leading role and influence the emergence of others. The typology of the demographic development by J.W. Webb showed that the shrinking of this city is more and more determined by the natural decline which outweighs the migration loss and which will decide about its shrinking in the long run. It was also indicated that the one-sided character of the former town economy concentrated on industrial culture strongly influenced the development of Wałbrzych in the following years. Changes in the economic base and problems on the local labour market which appeared with the political transformation are treated next to demographic changes as dominating reasons for the city's shrinkage. What followed was unfavourable changes in the socio-demographic structure of the city related to, e.g. the loss of human capital including the outflow of young and creative people and the aging of the inhabitants. The result of the shrinking process is also an unfavourable image which is difficult to break. The case of Wałbrzych shows that over the course of time the adopted regeneration strategies evolve, from those initially aiming at the improvement on the labour market to a more complex approach in which the main focus is on the qualitative development of the city. An important element of the regeneration strategy of this city is the use of the industrial heritage involving the development of new creative spaces. And although it did not solve the city's main problems, the positive effects of its implementation allowed strengthening its cultural potential and contributed to the city's better image. Moreover, the adopted programme of the city's revitalisation gives Wałbrzych the opportunity to enter the path of adaptation to the process of urban shrinkage.

Taking into account the demographic projections, Wałbrzych will still be shrinking. Its adaptation to the process of urban shrinkage and a long-term development vision for a smaller but more residentially friendly city seems to be of key importance for its future. Building awareness of the city's problems not only among local politicians and inhabitants but also among leading politicians will be a significant step towards this aim. However, the answer to the question whether it will be so and whether the city will be able to overcome the negative effects of the shrinkage and become a smaller but a better place to live for those staying there will be known in the years to come.

\section{References}

Beauregard R.A., 2003. Voices of decline. The post-war fate of US cities. Routledge, London/New York.

Bernt M., 2015. The limits of shrinkage: Conceptual pitfalls and alternatives in the discussion of urban population loss. International Journal of Urban and Regional Research 40(2): 441-450.

Bontje M., 2004. Facing the challenge of shrinking cities in East Germany: The case of Leipzig. GeoJournal 61(1): 13-21.

Bontje M., Musterd S. (eds), 2012. Understanding shrinkage in European regions. Built Environment 38/2: 153-161.

Caldwell J.C., Schindlmayr T., 2003. Explanations of the fertility crisis in modern societies: A search for commonalities. Population Studies 57(3): 241-263.

Cunningham-Sabot E., Jaroszewska E., Fol S., Roth S., Stryjakiewicz T., Wiechmann T., 2010. Processus de decroissance urbaine. In: Baron M., Cunningham-Sabot E., Grasland C., Riviere D., Van Hamme G. (eds), Ville et regions europeennes en decroissance. Lavoisier, Paris: 187-212.

Danielzyk R., Mielke B., Zimmer-Hegmann R., 2002. ILS Beiratsbericht Demographische Entwicklung - Schrumpfende Stadt, Institut für Landes- und Stadtentwicklungsforschung des Landes Nordrhein-Westfalen, Dortmund.

Domański B., 2000. The impact of spatial and social qualities on the reproduction of local economic success: The case of the path dependent development of Gliwice. Studies in local and regional development. Prace Geograficzne 106: 35-53.

Dziennik Gazeta Prawna, 2014. Wittenberg A., Zostało nam tylko łupanie węgla, wywiad z Grzegorzem Wałowskim ('All we had to do was crush the coal', an interview with Grzegorz Wałowski).

Gajda M., 2010. Wałbrzych naznaczony węglem. Od etosu górnika do stygmatu bieda szybownika (Wałbrzych marked with coal. From the miner's ethos to the stigma of the poor's shaft worker). In: Kamińska K. (ed.), Miejskie wojny. Edukacyjne dyskursy przestrzeni (Urban wars. Educational discourses of space). Oficyna Wydawnicza ATUT, Wrocław: 87-102. 
Gazeta Wyborcza, 2013. Wałbrzych podnosi się z kolan (Wałbrzych is raising from its knees), (author: Harłukowicz J.).

Gazeta Wyborcza/Wrocław, 2014. Prezydent Szełemej: Wałbrzych wychodzi z etapu kopalnianego (Wałbrzych emerges from the mine age) (author: Harłukowicz J.).

GUS - Główny Urząd Statystyczny (Statistics Poland): www. stat.gov.pl

Haase A., Bernt M., Großmann K., Mykhnenko V., Rink D. 2013. Varieties of shrinkage in European cities. European Urban and Regional Studies 12: 1-17.

Haase A., Nelle A., Mallach A., 2017. Representing urban shrinkage - The importance of discourse as a frame for understanding conditions and policy. Cities 69: 95-101.

Haase A., Rink D., Grossmann K., Bernt M., Mykhnenko V., 2014. Conceptualizing urban shrinkage. Environment and Planning 46: 1519-1534.

Hollander J.B., Pallagst K., Schwarz T., Popper F.J., 2009. Planning shrinking cities. Progress in Planning 72: 223 232.

Hospers G.J., 2012. Urban shrinkage and the need for civil engagement. In: Haase A., Hospers G.J., Pekelsma S., Rink D. (eds), Shrinking areas: Front runners in innovative citizen participation. The Hague: EUKN.

Hospers G.J., 2014a. Policy responses to urban shrinkage: From growth thinking to civic engagement. European Planning Studies 22(7): 1507-1523.

Hospers G.J., 2014b. Urban shrinkage in the EU. In: Richardson H.W., Nam C.W. (eds), Shrinking cities: A global perspective. Routledge, Abingdon.

Jarczewski W. (ed.), 2009. Przestrzenne aspekty rewitalizacji śródmieścia, blokowiska, tereny poprzemystowe, pokolejowe i powojskowe. Rewitalizacja miast polskich (Spatial aspects of revitalisation - downtowns, housing estates, brownfield sites, former railway and post-military areas. Regeneration of Polish cities), t. 4. Instytut Rozwoju Miast, Kraków

Jaroszewska E., 2014. Wałbrzych - dziedzictwo przeszłości a wyzwania przyszłości (Walbrzych - the legacy of the past and the challenges of the future). In: Stryjakiewicz T. (ed.), Kurczenie się miast w Europie Środkowo-Wschodniej (Urban shrinkage in East-Central Europe). Bogucki Wydawnictwo Naukowe, Poznań: 102-114.

Jaroszewska E., Stryjakiewicz T., 2014. Kurczenie się miast w Polsce (Shrinking cities in Poland). In: Stryjakiewicz T. (ed.), Kurczenie się miast w Europie Srodkowo-Wschodniej (Urban shrinkage in East-Central Europe). Bogucki Wydawnictwo Naukowe, Poznań.

Kabisch S., Sagan I., 2011. The inner city in focus. In: Haase A., Steinführer A., Kabisch S., Grossmann K., Hall R. (eds), Residential change and demographic challenge. The inner city of East Central Europe in the 21st century. Ashgate, Farnham, Surrey.

Kaczmarek T., 2001. Rewitalizacja miast w Polsce na tle doświadczeń europejskich (Regeneration of Polish against the background of European experience). In: Billert A. (ed.), Nowoczesne zarzadzanie rozwojem miast (Modern governance of urban development), Collegium Polonicum, Projekt Tempus - Phare, Słubice.

Kantor-Pietraga I., Krzysztofik R., Runge J., Spórna T., 2014. Problemy zarządzania miastem kurczącym się na przykładzie Bytomia (Problems with governing the shrinking city on the example of Bytom). In: Markowski T., Stawasz D. (eds), Społeczna odpowiedzialność w procesach zarządzania funkcjonalnymi obszarami miejskimi (Social responsibil- ity in the governance of functional urban areas). Biuletyn KPZK PAN 253: 162-175.

Klaassen L.H., Van den Berg L., 1988. Problemy przestrzenne (Spatial issues). In: Klaassen L.H., Myśl i praktyka ekonomiczna a przestrzeń (Thought and economic practice versus space). Wydawnictwo Uniwersytetu Łódzkiego, Łódź.

Knox P.L., Pinch S., 2010. Urban social geography: An introduction. Pearson Education, London.

Kosiński L., 1967. Geografia ludności (Population geography). Państwowe Wydawnictwo Naukowe. Warszawa.

Kosmaty J. 2011. Wałbrzyskie tereny pogórnicze po 15 latach od zakończenia eksploatacji węgla (Post-mining areas of Wałbrzych 15 years after the end of coal exploitation). Górnictwo i Geologia 6(1).

Krygowska N., 2016. Biedaszyby jako obszar formowania się subkultury pogórniczej (Poor's shafts as an area of the formation of post-mining subculture). In: Filimowska A., Krygowska N. (eds), Wałbrzych miasto poszukiwaczy (Wałbrzych - the city of explorers), Kraków, Wydawnictwo AGH: 45-60.

Kuciński K., 2008. Miasto w procesie dezindustrializacji (The city in the desindustrialisation process). In: Morawski W., Zawistowski A. (eds), Stare okregi przemystowe dylematy industrializacji $i$ dezindustrializacji (Old industrial districts, dilemmas of industrialisation and desindustrialisation). SGH, Warszawa: 161-179.

Kurkiewicz J. (ed.), 2010. Procesy demograficzne $i$ metody ich analizy (Demographical processes and methods of their analysis). Wydawnictwo Uniwersytetu Ekonomicznego w Krakowie, Kraków.

Lesthaeghe R., van de Kaa D., 1986. Twee Demografische Transities? In: Lesthaeghe R., van de Kaa D. (eds), Bevolking: Groei en Krimp. Van LoghumSlaterus, Deventer.

Majer A., 2014. Odrodzenie miast (Revitalisation of cities). Wydawnictwo UŁ, Wydawnictwo Naukowe Scholar, Warszawa - Łódź.

Niezbędnik Inteligenta (The essentials of an intellectual), 2014. Polityka, Wydanie specjalne.

Okólski M., 2005. Demografia. Podstawowe pojęcia, procesy i teorie w encyklopedycznym zarysie (Demographics. Basic concepts, processes and theories in an encyclopedic outline). Wydawnictwo Naukowe Scholar, Warszawa.

Oswalt P. (ed.), 2005. Shrinking cities. International research (Vol. 1). Hatje Cantz Verlag, Ostfildern.

Oswalt P., Rieniets T. (eds), 2006. Atlas of shrinking cities. Hatje canz Verlag: Ostfildern-Ruit.

Pacione M., 2005. Urban geography: A global perspective. Third Edition. Routledge, New York.

Pallagst K., Aber J., Audirac I., Cunningham-Sabot E., Fol S., Martinez-Fernandez C., Moraes S., Mulligan H., Vargas-Hernandez J., Wiechmann T., Wu T. (eds), 2009. The future of shrinking cities - Problems, patterns and strategies of urban transformation in a global context. Center for Global Metropolitan Studies, UC Berkeley, Monograph Series.

Pallagst K., Wiechmann T., Martinez-Fernandez C. (eds), 2014. Shrinking cities. International perspectives and policy implications. Routledge Advances in Geography. Routledge, New York.

Panorama Wałbrzyska, 2014. Wałbrzyskie centrum nudy pustoszeje. Czy jest szansa by odmienić rynek? (The centre of boredom in Wałbrzych is emptying. Is there a chance to change the market?) (author: Gołębiowski P.). 
Parysek J.J., Wdowicka M., 2002. Polish socio-economic transformation. Winners and losers at the local level. European Urban and Regional Studies 9: 60-72.

Parysek J.J., 2005. Miasta polskie na przełomie XX $i$ XXI wieku: Rozwój i przekształcenia strukturalne (Polish cities at the turn of the 21st century: Development and structural transformations). Bogucki Wydawnictwo Naukowe, Poznań.

Picht G., 1981. Odwaga utopii (Courage of utopia). Państwowy Instytut Wydawniczy, Warszawa.

Polityka, 2010. W mieście Czarnej Izy i Antka Kochanka (In the city of Black Iza and Antek the Lover) (author: Kyzioł A.)

Power A., Plöger J., Winkler A., 2010. Phoenix cities. The fall and rise of great industrial cities. Bristol University Press, Policy Press.

Rakowski T., 2009. Łowcy, zbieracze, praktycy niemocy (Hunters, gatherers, practitioners of powerlessness). Wydawnictwo Słowo/Obraz Terytoria, Gdańsk.

Reckien D., Martinez-Fernandez C., 2011. Why do cities shrink? European Planning Studies 9(8): 1375-1397.

Richardson H.W., Nam C.W. (eds), 2014. Shrinking cities. A global perspective. Routledge, Abingdon.

Roberts P., 2008. The evolution, definition and purpose of urban regeneration. In: Roberts P., Sykes H. (eds), Urban regeneration: A handbook. Sage Publications, London: 9-36.

Runge A., Kantor-Pietraga I., Runge J., Krzysztofik R., Dragan W., 2018. Can depopulation create urban sustainability in postindustrial regions? A case from Poland. Sustainability 10(12): 4633.

Runge J., Kantor-Pietraga I., Krzysztofik R., Runge A., 2015. Demograficzne przemiany rdzenia konurbacji katowickiej w latach 1990-2014 - w stronę modelu (Demographic changes of the core of the Katowice conurbation in the years 1990-2014 - towards the model). In: Wolaniuk A. (ed.), Wspótczesne czynniki i bariery rozwoju miast (Contemporary factors and barriers to urban development). XXVIII Konwersatorium Wiedzy o Mieście, Wydawnictwo Uniwersytetu Łódzkiego, Łódź: 247-257.

Sagan I., 2000. Miasto. Scena konfliktów i wspótpracy. Rozwój miast $w$ świetle koncepcji reżimu miejskiego (City. A scene of conflicts and cooperation. Urban development in the light of the urban regime concept). Wydawnictwo Uniwersytetu Gdańskiego, Gdańsk.

Skiba L. (ed.), 1997. Zagłębie węglowe w obliczu restrukturalizacji (Coal basin in the face of restructuring). Wydawnictwo Silesia, Wrocław.

Stryjakiewicz T. (ed.), 2014. Kurczenie się miast w Europie Środkowo-Wschodniej (Urban shrinkage in East-Central Europe). Bogucki Wydawnictwo Naukowe, Poznań.

Stryjakiewicz T., 1999. Adaptacja przestrzenna przemystu w Polsce w warunkach transformacji (Spatial adaptation of industry in Poland in the conditions of transformation). Wydawnictwo Naukowe UAM, Poznań.

Stryjakiewicz T., 2013. The process of urban shrinkage and its consequences. Romanian Journal of Regional Science, Special Issue "New Urban World" 7: 29-40.

Stryjakiewicz T., Jaroszewska E., 2016. The process of shrinkage as a challenge to urban governance. Quaestiones Geographicae 35(2): 27-39.

Stryjakiewicz T., Jaroszewska E., Marcińczak S., Ogrodowczyk A., Rumpel P., Siwek T., Slach O., 2014. Współczesny kontekst i podstawy teoretyczno-metodologiczne analizy procesu kurczenia się miast (Present-day context of the process of urban shrinkage and the theoretical and methodological foundations of its analysis). In: Stryjakiewicz T. (ed.), Kurczenie się miast w Europie Środkowo-Wschodniej (Urban shrinkage in East-Central Europe). Bogucki Wydawnictwo Naukowe, Poznań.

Stryjakiewicz T., 2013. The process of urban shrinkage and its consequences. Romanian Journal of Regional Science, Special Issue "New Urban World" 7: 29-40.

Turok I., Mykhnenko V., 2007. The trajectories of European cities, 1960-2005. The International Journal of Urban Policy and Planning 24(3): 165-182.

Urbański M., 2004. Restrukturyzacja gospodarki regionu watbrzyskiego: instrumenty, cele, środki (Restructuring of the economy of the Wałbrzych region: Instruments, goals, means). Uniwersytet Ekonomiczny w Poznaniu, Poznań (master's thesis).

Urząd Miejski w Wałbrzychu (Wałbrzych City Office), 2005. Strategia Zrównoważonego rozwoju miasta Wałbrzycha do $2013 r$. (Strategy for the sustainable development of Wałbrzych City till 2013).

Urząd Miejski w Wałbrzychu (Wałbrzych City Office), 2013. Wieloletni Program Gospodarowania Zasobem Mieszkaniowym Gminy Wałbrzych na lata 2014-2018 (A Long-term Programme for Managing Housing Resources of the Wałbrzych Commune for the years 2014-2018).

Urząd Miejski w Wałbrzychu (Wałbrzych City Office), 2016a. Gminny Program Rewitalizacji Miasta Watbrzycha na lata 2016-2025 (The Commune Revitalisation Programme for Wałbrzych city for the years 2016-2025).

Urząd Miejski w Wałbrzychu (Wałbrzych City Office), 2016b. Uchwata Rady Miejskiej Wałbrzycha w sprawie wyznaczenia obszaru zdegradowanego i obszaru rewitalizacji miasta Watbrzycha (Resolution of the Wałbrzych City Council on the designation of the degraded area and the area of revitalisation of the city of Wałbrzych).

Węcławowicz G., 2007. Geografia społeczna miast. Uwarunkowania spoteczno-przestrzenne (Social geography of cities. Socio-spatial determinants). Wydawnictwo Naukowe PWN, Warszawa.

Węcławowicz G., 2013. Transnational development strategy for the post-socialist cities of Central Europe. Institute of Geography and Spatial Organisation, Polish Academy of Sciences, Warsaw.

Wiechmann T., Bontje M., 2015. Responding to tough times: Policy and planning strategies in shrinking cities. European Planning Studies 23(1): 1-11.

Wiechmann T., Wolff M., 2013. Urban shrinkage in a spatial perspective - Operationalization of shrinking cities in Europe 1990-2010, AESOP-ACSP Joint Congress, 1519.07.2013. Dublin.

Wiechamnn T., Volkmann A., 2012. Making places in increasingly empty spaces: Causes and outcomes of demographic change in Germany In: Martinez-Fernandez C., Kubo N., Noya A., Weyman T. (eds), Demographic change and local development: Shrinkage, regeneration and social dynamics, OECD Centre of Entrepreneurship, Paris: 91-103.

WUS 1990, Wojewódzkie Urzędy Statystyczne (Voivodeship Statistical Offices), Ludność Miasta Wałbrzycha 1990.

Young \& Rubicam, 2009. Magnetyzm polskich miast, http:/ / wiadomosci.gazeta.pl/wiadomosci/1,114873,7253954,Bytom_Walbrzych_Ruda_Slaska_najbardziej_odpychajace.html (accessed: 10 December 2010).

Zborowski A., Soja M., Łobodzińska A., 2012. Population trends in Polish cities - stagnation, depopulation or shrinkage? Prace Geograficzne 130, Instytut Geografii i Gospodarki Przestrzennej UJ. Kraków: 7-28. 